Milica Perić ${ }^{1}$

Sanja Filipovic ${ }^{2}$
JEL: 011, C13, C52, F40 i F41

DOI: $10.5937 /$ industrija46-17408

UDC: 339.564(497.11)"2005/2016"

005.332

Original Scientific Paper

\title{
Impact of export determinants on the export sector in Republic of Serbia
}

\author{
Article history: \\ Received: 3 March 2018 \\ Sent for revision: 2 April 2018 \\ Received in revised form: 9 May 2018 \\ Accepted: 9 May 2018 \\ Available online: 29 June 2018
}

\begin{abstract}
In order to show the effect of export determinants on the export in the Republic of Serbia, this research comes to examine the correlation between export determinants and the degree of impact of export determinants on export in Republic of Serbia in the period of 2005-2016. This study applies the SPSS 23 software by Correlation matrix using Pearson coefficient in order to show the connection between export determinants and export, as well as the Linear Regression Models, in order to show the degree of impact of the export determinants on export. The analysis revealed the existence of the significant correlation between export and several hypothetical export determinants - import, GDP, GDP per capita, savings, population, employment, productivity of work, exchange rate, and consumption prices as well as the impact of those on export. It stresses as well that there is no relationship between export and FDI, investments, and industrial production.
\end{abstract}

Keywords: correlation, export, macroeconomic indicators, regression.

\section{Uticaj determinanti izvoza na izvozni sektor u Republici Srbiji}

Apstrakt: Cilj rada je da utvrdi stepen uticaja izabranih determinanti na izvoz Republike Srbije za vremenski period od 2005. do 2016. godine. U radu je primenjena korelaciona matrica i Pearson-ov koeficijent kako bi se utvrdila veza između determinanti izvoza i izvoza putem SPSS 23 softvera. Pored toga, da bi se utvrdio stepen uticaja determinanti korišćena je linearna regresija. Rezultati istraživanja pokazaju postojanje značajne korelacije

\footnotetext{
${ }^{1}$ Singidunum University, PhD student. email: milicamip@gmail.com

${ }^{2}$ Economics Institute, Belgrade
} 
Perić M., Filipović S.: Impact of export determinants on the export sector in Republic...

između izvoza i većeg broja determinanti izvoza, a to su: uvoz, BDP, BDP po broju stanovnika, štednja, stanovništvo, zaposlenost, produktivnost rada, kurs valute i potrošačke cene, kao i uticaj istih na izvoz. Analiza takođe pokazuje da ne postoji direktna veza između izvoza i stranih direktnih investicija (SDI), investicija $i$ industrijske proizvodnje.

Ključne reči: korelacija, izvoz, makro ekonomski indikatori, regresija.

\section{Introduction}

Over the last few decades, foreign trade balance in Republic of Serbia is permanently in deficit, i.e. imports are largely superior to exports. In 2000, Republic of Serbia officially adopted the concept of liberal market, which is still the subject of the criticism. Thus it was expected export to grow and overcome the long-time deficit. Foreign trade balance had its up and downs during the last two decades, but even after such a long period of time, in 2017 foreign trade balance is still in deficit. Even for these critiques, little attention has been devoted to study the impact of the export determinants upon the foreign trade evolution in Republic of Serbia. This paper seeks to address this gap in the literature. It argues that some of supposed export determinants, such as foreign direct investments (FDI), have no direct impact on exports in Republic of Serbia.

On the most general level, this research shows in what measure the export determinants impact on export sector in Republic of Serbia. The findings suggest that the export determinants such as FDI, investments and industrial production do not helpfully connect to the exports. Therefore, the argument may be read as a case specific partial confirmation of Krušković (2017). It also contradicts to the foreign authors concern (for instance Kunwang, Bingzhan, 2013) that FDI are crucial for exports. For this last, the explanation could lie in the impact of FDI on export within different economy management.

The aim of this paper is, firstly, to estimate the correlation of export determinants on the export and show which of supposed determinants have major impact on export in Republic of Serbia. Secondly, this study examines the degree of influence of each determinant of export on total export. As a result, this research points on the principal export determinants and their econometrical study in order to estimate which of the export determinants have the larger impact on it, as well as to prove that FDI does not influence exports directly.

The structure of this paper is the following: this first section provides a brief concept of foreign trade and export, as well as how this research intends to contribute to the literature. The second section provides further clarification of 
Perić M., Filipović S.: Impact of export determinants on the export sector in Republic...

how the argument of this paper connects with the relevant literature. In the progress, the third part defines the central terms of the analysis and clarifies the analytical and methodological choices, as well as the description of variables (determinants) chosen for this research. The components of the argument of this research are than econometrically supported in the main (fourth) section of this paper. Finally, in the fifth and the last part, this paper presents a set of suggestions for an improved foreign trade design, especially of the export sector in Republic of Serbia, before the brief conclusion of the research.

\section{Literature review}

Since Republic of Serbia is in transition, the country implemented the aggressive privatization model and liberalization of foreign trade and financial flows (Filipović, Miljković, 2014). In 2006, for example, Republic of Serbia signed the agreement with the EU in order to eliminate foreign trade costs of imports for EU countries under the Agreement on amendment of and accession to the agreement on free trade in Central Europe (CEFTA, 2006). At the beginning of the world financial crisis, in 2007, Serbia's imports had suffocated exports with $53.47 \%$, and in 2008 with $119.08 \%$, which is more than double in just one year time (Author's calculations). The study conducted in 2010, under the name of Post-crisis model of economic growth and development of Serbia 2011-2020, shows that Serbia should turn to a new model of economic development and economic growth, basically investment and export oriented. The authors of this study stand optimistic and argue that until 2020 export would reach 65 percent of GDP (MAT, FREN, 2010). According to the national data available for exports in 2017 and empirical evidences, it is obvious that until 2020 export would probably not reach that percentage not even close.

The empirical analysis engaged in foreign trade and export determinants have been conducted in many other countries in transition. Trade data from China's Annual Survey of Industrial Firms (1998-2007) shows the development of the Chinese ITC goods relies heavily on export markets. Therefore, exports are largely determined by FDI (increasing quality but decreasing quantity), processing trade (increasing quantity but decreasing quality) and government supporting policies (suggesting challenging attitude versus growing highquality production and increase in employment), especially because of the foreign affiliates and reorganization of production in Asia (Kunwang, Bingzhan, 2013).

The strong concentration of FDI is relevant in the regions of some countries where the state aid is becoming inefficient, while the results for Serbia appear 
Perić M., Filipović S.: Impact of export determinants on the export sector in Republic...

low not because of lack of state aid but because of the decrease in FDI concentration inflow, calculated through Gini index and relative entropy index (Makojević et al, 2016). However, the general results of Zhang indicate that the role of exports in economic development depends largely on the particular situation of each region, as well as FDI being significant in all cases, but the contribution of FDI to overall economic growth is critical (Zhang, 2012).

The measurement of the index of export "sophistication" provides a new and useful way of analyzing trade and location patterns as well as the country competitiveness analysis (Lall et al, 2005). All these export factors (technology, marketing, logistics and proximity, fragmentability, information and familiarity, natural resources, infrastructure, value chain organization, which changes over time) make understandable the complex network of factors influencing export sector. According to Chou et al (2008), the study of single industry sector for import proved that a modified regression model with non-static variable for forecasting volumes of Taiwan's import containers offers the higher prediction accuracy and thus overcomes the traditional regression model for the same case. Therefore, if a country is able to predict the volume of imports, it would be able to adequatly manage the exports.

Radojević et al (2015) argue that FDI is beneficial for foreigners to invest in Serbia because of its favourable geographical area, high level of education and skilled personell, English speaking people and (free) trade agreements with many countries. Serbia represents the connection between East and West therefore it is able to attract FDI even if suffered the recent global economic crisis. Yet, considering the advantages of Serbia, Nikolić and Bodroža (2012) aim on brand positioning of Serbia as element important for bettering export and in their study export has the greatest weight and influence (0.79), followed by FDI (0.17) and finally tourism (0.04). Rounding off implications of FDI, the analysis of the past trends in export and FDI inflows shows up as crucial. Therefore, if export sector fails to perform properly, national brand would not show up brilliant, pushing the economy to import and carry forward the trade balance deficit.

Duenas-Caparas (2007) has investigated the factors that influence the firms to export and proved that many of supposed determinants do not influence directly the exports, such as firm age, human capital, and research and development (R\&D) expenditure. From the other side, the firm size is assumed to be important but with negative or no relationship with exports. In the foreign affiliation that has the most prominent influence on firm's propensity to export, human capital is related to the competitiveness of export market but Hecksher-Ohlin model shows there is a statistically negative relationship with export performance considered to be costly to invest in. As well, the study found out that foreign investments in local firms and in export activities are positively related (mainly because of the multinational 
Perić M., Filipović S.: Impact of export determinants on the export sector in Republic...

companies influence), and capital intensity is determinanting export performance. Finally, Duenas-Caparas (2007) found a positive connection between workforce training and export performance, and the author wanted to use that data here, but there is no precise data set available for Serbia.

Regarding R\&D variable, Vasić et al (2016) prove the opposite attitude, stressing that $R \& D$ expenditures are an important precondition for the economic growth and development, as well as for the improvement of export performances and competitiveness of national economies. However, the advantage is obtainable only with constant innovations in new products and new technology, leading to affirm the positive correlation between R\&D investments and export growth rate.

According to Learner (1980) the model of interdependence between human capital and foreign trade it's known as Leontief paradox, and the theory is based on the different interpretations. One explanation is that the theoretical approach is based on wrong presumes. According to Petrović, (2010), the human capital is different from the material capital because it loses on its value when not in use, which occures in the case of unemployment.

Zubritskiy (2014), comparing data of 2007 and 2011, concluded that reducing the product assortment and loosing the export markets typical for Ukraine, are the world trends. However, crisis phenomena at the world markets stopped the trend of unchangeable exports and caused Ukrainian export diversification level to increase: in export sector normalized Herfindahl concentration index increased from 0.011 in 2007 to 0.015 in 2011 . The fact that the country does not export the goods which are in demand at world markets, testifies about significant export potential and necessity in its implementation stimulating both extensively and intensively.

According to Pakhomov (2015), decrease in export (around 4\%) first time after five years occured in 2014 in Russia. Decrease in oil price and depreciation of ruble led to rigidity of the Russian foreign economic relations, which added new risks and limitations for export development. The author considers, however, that the most important strategy for Russia is to develop a program for foreign economic complex in order to face depreciation of ruble and increase total export. A similar attitude regarding Russian foreign trade occupied Knobel (2016) who argued that there is the surplus of the trade balance even if export volume declined in chemical products and machinery equipment, whereas the decline hits most mineral products, textiles and footwear. This decline explaines that importers tend to refocus toward cheaper imported commodities, on one side, and depreciation of the national currency of the most important importing countries, on the other side. To highlight the research, not any success has been achieved in selling groups of commodities at the lower prices. 
Perić M., Filipović S.: Impact of export determinants on the export sector in Republic...

Through the empirical estimation of the equilibrium exchange rate level of dinar (Serbian national currency), Pažun et al (2016) showed that the dinar over-evaluate over medium term under unchanged economic policy, taking into consideration import and export elasticity. In addition, Krušković (2017) stressed out how both exchange rate and interest rate have impact on movement of nominal and real economic variables, so than on exports and imports, as well as that exchange rate affects aggregate demand especially in small and open economies. Additionally, Nikolić (2005) concludes that openness influences the Serbian economic growth, and that there is a focus on conducting healthy monetary and fiscal policy, realization of stability of the exchange rate and decreasing of the level of corruption.

In the recent study about export of Serbian fresh tomato, conducted by Vuković et al (2015), autors insist on the possibility of fresh tomato to be dominant in the exports of the country. Even if the export of fresh tomato is fluctuating, it is still representing increasing trend and encouraging entrepreneurs to implement activities necessary for inclusion of Serbia in the international tomato market. Lack of high-tech and high prices lead tomato production to be uncompetitive on the global market, in spite of convenient climate, spill and excellent geostrategic position.

In view of these findings, it is reasonable to belive that FDI, investments, exchange rate, consumption prices, and employment affect the degree of impact on export in Republic of Serbia. It would be preferable to include human capital in calculations of the degree of its impact on export, but unfortunately, in Serbia as in many other countries, the factor of work is measurable in time units, and does not take into account the real quality of work. Regarding one supposed important variable of export, inflation rate, in this research will not appear as a separate variable, since here is used the real exchange rate. Moreover, this research includes savings as one of the supposed export determinants, inspired by economic theory, such as SolowSwan model. The literature engaged here provided empirical analysis on the export determinants stressing, between others, how the variables mentioned above impact on export sector. However, none of these studies observed the degree of impact of the export deteminants on export in Republic of Serbia.

\section{Research methodology}

The purpose of this section is to present the methodological issues used in this paper, as well as to argue the choices of the models employed.

The aim of this research is to: 
Perić M., Filipović S.: Impact of export determinants on the export sector in Republic...

- Estimate the weight of export determinants and evaluate the degree and significance of those on exports, i.e. the correlation between independent variables and export, using the data from 2005 to 2016 for Republic of Serbia, and

- Demonstrate that variables such as import, GDP, GDP per capita, population, employment, savings, productivity of work, exchange rate, consumption prices impact on exports, i.e. that FDI, investments and industrial production have no direct impact on exports.

In order to evaluate the export determinants the macroeconomic approach was employed. It consists in three steps: correlation analysis, regression models, and setting the fundamental variable(s). The aim of correlation analysis is to verify if there is a quantitative connection between variables and the degree of connection. Therefore, in order to estimate whether there is a significant impact of factor(s) in examination on exports, the paper use: first, the model of simple linear regression (SLR), in order to estimate the degree of impact of each variable on export, and, second, the model of multiple linear regression analysis (MLR). SLR model is the function where the dependent variable is determined by one independent variable:

$Y_{i}=\beta_{0}+\beta_{1} x_{1}+e_{i}$

while, MLR is expressed as follows:

$Y_{i}=\beta_{0}+\beta_{1} x_{1 i}+\cdots+\beta \square x \square i+\cdots+\beta \square x \square i+e_{i}$

where:

$Y_{i}$ - dependent variable,

$\beta_{0}-$ coefficient of regression

$\beta_{1} x_{1}, \beta_{2} x_{2 i} \ldots \beta \square x \square i \ldots \beta \square x \square i-$ independent variable(s),

$e_{i}-$ random error of the model.

However, after estimating export determinants and obtaining the relevant variables, it follows the analysis of the multiple regression model taking into account only relevant variables that influence export which resulted from SLR models. In conducting the first two steps the research would estimate which variable is the most important, i.e. which determinant of export have quantitatively the highest impact on export. In addition, for both correlation and regression analysis, the statistical significance ( $p$-value) is a parameter that determines the likelihood a given result occurs by chance. In the case of simple and multiple regressions, $p$-value associated with $\mathrm{R}$-square indicates the significance of the association of dependent and independent variables.

Data used for modeling in this research are provided from Statistical Office of Serbia - RZS - (section: data base) and National Bank of Serbia - NBS - 
Perić M., Filipović S.: Impact of export determinants on the export sector in Republic...

(section: statistics). The data are expressed in million of euros (GDP, GDP per capita, export, import, savings, FDI, investments), percentages (consumption prices trend), and absolute numbers and indexes (population, employment, exchange rate, productivity of work, industrial production). The Table 1 contains the description of variables mentioned above.

Table 1. Descrition of variables

\begin{tabular}{|c|c|c|c|}
\hline \multicolumn{2}{|r|}{ Description of variables - units of measure } & \multirow{2}{*}{$\begin{array}{c}\text { Source } \\
\text { NBS - RZS }\end{array}$} & \multirow{2}{*}{$\mathbf{N}$} \\
\hline Export & in milion euros - total export & & \\
\hline Import & in milion euros - total import & NBS - RZS & 2 \\
\hline GDP & $\begin{array}{l}\text { in milion euros - at current prices - indicates the } \\
\text { market value of production in a country during a year }\end{array}$ & NBS & 3 \\
\hline GDP per capita & $\begin{array}{l}\text { in milion euros - at current prices - indicates the } \\
\text { market value of production in a country during a year } \\
\text { per citizen }\end{array}$ & NBS & 4 \\
\hline Population & number of population by large age groups and gender & RZS & 5 \\
\hline Employment & $\begin{array}{l}\text { number of employees in legal entities plus the } \\
\text { number of entrepreneurs and their employees } \\
\text { (excluding registered individual farmers) }\end{array}$ & NBS - RZS & 6 \\
\hline Savings & $\begin{array}{l}\text { in milion euros, total savings = short+long term } \\
\text { savings }\end{array}$ & NBS & 7 \\
\hline Investments & $\begin{array}{l}\text { in milion euros - in fixed assets, at current prices - } \\
\text { comprehend the investments of all legal entities and } \\
\text { individuals in the country }\end{array}$ & RZS & 8 \\
\hline Productivity & $\begin{array}{l}\text { productivity of labour or productivity of work is the } \\
\text { rate of output per worker calculated as division of } \\
\text { GDP/number of employees }\end{array}$ & RZS & 9 \\
\hline FDI active & $\begin{array}{l}\text { in milion euros - investment by residents in non- } \\
\text { resident legal entities, sale and purchase of real } \\
\text { estate abroad. }\end{array}$ & $\begin{array}{l}\text { NBS - } \\
\text { Ministry of } \\
\text { Finance }\end{array}$ & 10 \\
\hline FDI passive & $\begin{array}{l}\text { in milion euros - investments of non-residents to } \\
\text { resident legal entities, sale and purchase of real } \\
\text { estate in Serbia. }\end{array}$ & $\begin{array}{l}\text { NBS - } \\
\text { Ministry of } \\
\text { Finance }\end{array}$ & 11 \\
\hline Exchange rate & $\begin{array}{l}\text { average exchange rate of the dinar against a foreign } \\
\text { currency for a particular month/year. }\end{array}$ & NBS & 12 \\
\hline Consumption prices & $\begin{array}{l}\text { in } \% \text { - at the end of the period - weights represent the } \\
\text { structure of household consumption. }\end{array}$ & RZS & 13 \\
\hline Industrial Production & $\begin{array}{l}\text { a tendency of changes - in percentage - in the } \\
\text { development of the industry and its dynamics in the } \\
\text { corresponding period in comparison with the base } \\
\text { period in a particular territory. Base year is } 2010 \text {. }\end{array}$ & RZS & 14 \\
\hline $\begin{array}{l}\text { N.B. Methodology used by } \\
\text { http://www.stat.gov.rs/W } \\
\text { https://www.nbs.rs/intern }\end{array}$ & $\begin{array}{l}\text { RZS are available on the link } \\
\text { VebSite/Public/PageView.aspx?pKey=4 and by NBS are availab } \\
\text { net/cirilica/80/index.html for each area of research }\end{array}$ & link & \\
\hline
\end{tabular}

Source: Author's elaboration 
Perić M., Filipović S.: Impact of export determinants on the export sector in Republic...

\section{Empirical results and discussion}

Since the purpose of this section is to present the results of the methodology, their interpretation in the context of the research and the literature, the obtained results are as follows. Firstly, the Table 2 traces the correlation between all variables of the model.

Table 2. Correlation matrix

\begin{tabular}{|c|c|c|c|c|c|c|c|c|c|c|c|c|c|c|c|}
\hline \multicolumn{16}{|c|}{ Correlations } \\
\hline & & Exports & Import & GDP & $\begin{array}{l}\text { GDPpe } \\
\text { rcapita }\end{array}$ & $\left|\begin{array}{c}\text { Populat } \\
\text { ion }\end{array}\right|$ & $\mid \begin{array}{c}\text { Employ } \\
\text { ment }\end{array}$ & Savings & $\begin{array}{l}\text { Invest } \\
\text { ments }\end{array}$ & $\begin{array}{l}\text { Produ } \\
\text { ctivity }\end{array}$ & $\begin{array}{c}\text { FDI } \\
\text { active }\end{array}$ & \begin{tabular}{|c} 
FDI \\
passiv \\
$e$
\end{tabular} & \begin{tabular}{|c|} 
Excha \\
nge \\
Rate \\
\end{tabular} & \begin{tabular}{|c} 
Conspr \\
ices\%tr \\
end
\end{tabular} & $\begin{array}{c}\text { IndProd } \\
(2010= \\
100)\end{array}$ \\
\hline \multirow[t]{3}{*}{ Exports } & Pearson Correlation & 1 & $.890^{\circ}$ & $.798^{* \prime}$ & $.845^{\circ}$ & $-.980^{*}$ & $-.751^{\prime \prime}$ & $.903^{*}$ & -.134 & $.844^{\prime \prime}$ & -.085 & -289 & $.909^{\prime \prime}$ & $-.803^{*}$ & .169 \\
\hline & Sig. (2-tailed) & & .000 & .002 & .001 & .000 & .005 & .000 & 678 & .001 & .816 & .418 & .000 & .002 & .599 \\
\hline & $N$ & 12 & 12 & 12 & 12 & 12 & 12 & 12 & 12 & 12 & 10 & 10 & 12 & 12 & 12 \\
\hline \multirow[t]{3}{*}{ Import } & Pearson Correlation & $.890^{\circ}$ & 1 & $.925^{*}$ & $.938^{* \prime}$ & $-.830^{*}$ & $-618^{*}$ & $.827^{*}$ & .312 & $.890^{\circ}$ & .153 & -.033 & $.680^{\circ}$ & $-.701^{*}$ & .368 \\
\hline & Sig. (2-tailed) & .000 & & .000 & .000 & .001 & .032 & .001 & .323 & .000 & .673 & .929 & .015 & .011 & .239 \\
\hline & $N$ & 12 & 12 & 12 & 12 & 12 & 12 & 12 & 12 & 12 & 10 & 10 & 12 & 12 & 12 \\
\hline \multirow[t]{3}{*}{ GDP } & Pearson Correlation & $.798^{\prime \prime}$ & $.925^{\circ}$ & 1 & $.996 "$ & $-.776 "$ & $-.715^{*}$ & $.868^{* \prime}$ & .385 & $.972^{*}$ & -.242 & .024 & $.638^{*}$ & $-.707^{*}$ & .138 \\
\hline & Sig. (2-tailed) & .002 & .000 & & .000 & .003 & .009 & .000 & 216 & .000 & .500 & .948 & .026 & .010 & .668 \\
\hline & $\mathrm{N}$ & 12 & 12 & 12 & 12 & 12 & 12 & 12 & 12 & 12 & 10 & 10 & 12 & 12 & 12 \\
\hline \multirow{3}{*}{$\begin{array}{l}\text { GDPper } \\
\text { capita }\end{array}$} & Pearson Correlation & $.845^{\prime \prime}$ & $.938^{\prime \prime}$ & $.996^{*}$ & 1 & $-.827^{* 1}$ & $-.748^{*}$ & $.900^{*}$ & .316 & $.981^{\prime \prime}$ & -.241 & -.068 & $.697^{\circ}$ & -.734 & .127 \\
\hline & Sig. (2-tailed) & .001 & .000 & .000 & & .001 & .005 & .000 & 316 & .000 & .502 & .853 & .012 & .007 & .694 \\
\hline & $\mathrm{N}$ & 12 & 12 & 12 & 12 & 12 & 12 & 12 & 12 & 12 & 10 & 10 & 12 & 12 & 12 \\
\hline \multirow{3}{*}{$\begin{array}{c}\text { Populat } \\
\text { ion }\end{array}$} & Pearson Correlation & $-.980^{\circ \prime}$ & $-830^{\circ}$ & $-.776^{*}$ & $-.827^{\circ}$ & 1 & $.840^{\circ}$ & $-.945^{*}$ & 197 & $-855^{\prime \prime}$ & .201 & .396 & -.966 & $.761^{*}$ & .010 \\
\hline & Sig. (2-tailed) & .000 & .001 & .003 & .001 & & .001 & .000 & .540 & .000 & .577 & .257 & .000 & .004 & .975 \\
\hline & $\mathrm{N}$ & 12 & 12 & 12 & 12 & 12 & 12 & 12 & 12 & 12 & 10 & 10 & 12 & 12 & 12 \\
\hline \multirow{3}{*}{$\begin{array}{c}\text { Employ } \\
\text { ment }\end{array}$} & Pearson Correlation & $-.751^{\prime \prime}$ & $-.618^{\circ}$ & $-.715^{\prime \prime}$ & $-.748^{*}$ & $.840^{\circ}$ & 1 & $-.936^{*}$ & .128 & -858 & .396 & .529 & $-.881^{\prime \prime}$ & .543 & .424 \\
\hline & Sig. (2-tailed) & .005 & .032 & .009 & .005 & .001 & & .000 & .692 & .000 & .257 & .116 & .000 & .068 & .170 \\
\hline & $\mathrm{N}$ & 12 & 12 & 12 & 12 & 12 & 12 & 12 & 12 & 12 & 10 & 10 & 12 & 12 & 12 \\
\hline \multirow[t]{3}{*}{ Savings } & Pearson Correlation & $.903^{\prime \prime}$ & $.827^{\prime \prime}$ & $.868^{\circ \prime}$ & $.900 "$ & -.945 & -.936 & 1 & -.017 & $.949^{\prime \prime}$ & -308 & -.502 & $.915^{\prime \prime}$ & $-.697^{\circ}$ & -.144 \\
\hline & Sig. (2-tailed) & .000 & .001 & .000 & .000 & .000 & .000 & & .957 & .000 & .387 & .139 & .000 & .012 & .654 \\
\hline & $\mathrm{N}$ & 12 & 12 & 12 & 12 & 12 & 12 & 12 & 12 & 12 & 10 & 10 & 12 & 12 & 12 \\
\hline \multirow{3}{*}{$\begin{array}{c}\text { Investm } \\
\text { ents }\end{array}$} & Pearson Correlation & -.134 & .312 & .385 & .316 & .197 & .128 & \begin{tabular}{|c|c|}
-017 \\
\end{tabular} & 1 & 233 & .380 & .394 & -.353 & .074 & .307 \\
\hline & Sig. (2-tailed) & .678 & .323 & .216 & .316 & .540 & .692 & .957 & & .467 & .279 & .260 & .260 & .818 & .332 \\
\hline & & 12 & 12 & 12 & 12 & 12 & 12 & 12 & 12 & 12 & 10 & 10 & 12 & 12 & 12 \\
\hline \multirow{3}{*}{\begin{tabular}{|c|}
$\begin{array}{c}\text { Product } \\
\text { ivity }\end{array}$ \\
\end{tabular}} & Pearson Correlation & $.844^{\prime \prime}$ & $.890^{\prime \prime}$ & .972 & .981 & $-.855^{*}$ & $-.858^{\prime \prime}$ & $.949^{*}$ & .233 & 1 & -.345 & -252 & $.766 "$ & $-.708^{*}$ & -.032 \\
\hline & Sig. (2-tailed) & .001 & .000 & .000 & .000 & .000 & .000 & .000 & .467 & & .328 & 482 & .004 & .010 & .922 \\
\hline & $\mathrm{N}$ & 12 & 12 & 12 & 12 & 12 & 12 & 12 & 12 & 12 & 10 & 10 & 12 & 12 & 12 \\
\hline \multirow{3}{*}{\begin{tabular}{|c} 
FDI \\
active
\end{tabular}} & Pearson Correlation & -.085 & .153 & -.242 & -.241 & .201 & .396 & -.308 & .380 & -345 & 1 & .406 & -.302 & .209 & .534 \\
\hline & Sig. (2-tailed) & .816 & .673 & .500 & .502 & .577 & .257 & .387 & .279 & .328 & & .245 & .396 & .563 & .112 \\
\hline & $N$ & 10 & 10 & 10 & 10 & 10 & 10 & 10 & 10 & 10 & 10 & 10 & 10 & 10 & 10 \\
\hline \multirow{3}{*}{\begin{tabular}{|c|} 
FDI \\
passive
\end{tabular}} & Pearson Correlation & -289 & -.033 & .024 & -.068 & .396 & .529 & -.502 & .394 & -.252 & .406 & 1 & -.565 & .095 & .474 \\
\hline & Sig. (2-tailed) & .418 & .929 & .948 & .853 & .257 & .116 & .139 & .260 & .482 & .245 & & .089 & .795 & .166 \\
\hline & $\mathrm{N}$ & 10 & 10 & 10 & 10 & 10 & 10 & 10 & 10 & 10 & 10 & 10 & 10 & 10 & 10 \\
\hline \multirow{3}{*}{$\begin{array}{l}\text { Exchan } \\
\text { geRate }\end{array}$} & Pearson Correlation & $.909^{\prime \prime}$ & $.680^{\circ}$ & $.638^{\circ}$ & $.697^{\circ}$ & -.966 & $-.881^{\prime \prime}$ & $.915^{\circ}$ & -353 & $.766^{*}$ & -302 & -.565 & 1 & $-.664^{*}$ & -.197 \\
\hline & Sig. (2-tailed) & .000 & .015 & .026 & .012 & .000 & .000 & .000 & .260 & .004 & .396 & .089 & & .018 & .539 \\
\hline & $\mathrm{N}$ & 12 & 12 & 12 & 12 & 12 & 12 & 12. & 12 & 12 & 10 & 10 & 12 & 12 & 12 \\
\hline \multirow{3}{*}{$\begin{array}{c}\text { Conspri } \\
\text { ces\%tr } \\
\text { end }\end{array}$} & Pearson Correlation & $-.803^{\prime \prime}$ & $-.701^{\circ}$ & $-.707^{\circ}$ & $-.734^{4}$ & $.761^{\circ}$ & .543 & $-697^{\circ}$ & .074 & $-.708^{*}$ & .209 & .095 & $-.664^{*}$ & 1 & -.140 \\
\hline & Sig. (2-tailed) & .002 & .011 & .010 & .007 & .004 & .068 & .012 & .818 & .010 & .563 & .795 & .018 & & .663 \\
\hline & $\mathrm{N}$ & 12 & 12 & 12 & 12 & 12 & 12 & 12 & 12 & 12 & 10 & 10 & 12 & 12 & 12 \\
\hline \multirow{3}{*}{$\begin{array}{c}\text { IndProd } \\
(2010= \\
100)\end{array}$} & Pearson Correlation & .169 & .368 & .138 & .127 & .010 & .424 & -.144 & .307 & -.032 & .534 & .474 & -.197 & -.140 & 1 \\
\hline & Sig. (2-tailed) & .599 & .239 & .668 & .694 & .975 & .170 & .654 & .332 & .922 & .112 & .166 & .539 & .663 & \\
\hline & $\mathrm{N}$ & 12 & 12 & 12 & 12 & 12 & 12 & 12 & 12 & 12 & 10 & 10 & 12 & 12 & 12 \\
\hline
\end{tabular}

Source: Author's calculation 
Perić M., Filipović S.: Impact of export determinants on the export sector in Republic...

The first observed variable is import. As expected, import has relevant correlation to export (0.890), i.e. import represents very strong positive correlation to export and it is statistically significant. Experience of previous econometrical studies proved the strong correlation between import and export, demonstrating that import phenomena impact on export in particular because of importation of raw material.

Similarily, GDP has strong positive correlation to export (0.798) and is statistically significant, demonstrating that the higher the GDP the higher the exports, mostly because the availability of currency allows the state and owners to invest in production and increase the export. GDP per capita, also statistically significant, is even more positively correlated to export $(0.845)$. Result to be expected, since the higher the individual financial availability the more the possibility to maintain or start the enterprise and export the production. As reminder, exports were $25 \%$ in GDP in 2005, since when it follows the increasing trend, interrupted only in the year of the crisis with just $2 \%$ of decrease in GDP in respect to the previous year, i.e. $28 \%$ of GDP and $26 \%$ GDP in 2007 and 2008, respectively, while in 2016 it reached $51 \%$ in GDP (see Table 4).

Population represents the almost perfect negative correlation with exports (0.980 ), and it is statistically significant, which means the lower the population the higher the export. One of the interpretations could be - the less the population consumes goods and services the higher quantity would be available for export. From the other side, there are much more realistic interpretations. For example, when great projects in infrastructure take place, like construction of roads, buildings or bridges in the country and employ ten or twenty thousand people at once, their engagement and their salaries have no effect on export, since the domestic construction is in question. Another example could be the labours in agriculture - hundreds of thousands of people engage in agriculture during the season but their wages do not benefit the national export. Secondly, while the population in Serbia is in constant decrease and export in continuous increase in the period in examination, some could suspect that this contrariwise movement may indicate that there is the correlation between two variables, but not necessarily. According to the author's calculations, increase in export from 2005 to 2016 is $69 \%$, while decrease in population for the same period is $5 \%$. The response is that this variation surely do not explain abovementioned.

Employment has strong negative correlation to export $(-0.751)$ and it is statistically significant, i.e. the higher the number of employees the weaker the export, and vice versa, interpretation which could seem strange, but realistic. Apparently, the result shows how technology and mechanization influence on the economic growth. As an example, several years ago the primary sector in Serbia passed through difficulties to produce enough quantity of fruit and 
Perić M., Filipović S.: Impact of export determinants on the export sector in Republic...

vegetables for the export. In the luck of machinery and new technology, small enterprises have had weak capacity to produce a certain quantity of fruits and vegetables good enough for export, while in the recent years, in the presence of "new tech" some companies enjoy the possibility to explore the production and export the products, partially or totally, and place them within a foreign market. In the situation of manufactures weakness in the ability to assure the overproduction, while receiving salaries from the owners, it complicates the possibility to export. In regards to employment, there was the continuous decreasing trend form 2005 to 2015 , which may be explained by the fall in the population (more than 400000 people), but this is not focus here. It is possible that decrease in employment increases the export, demonstrating thus how the economy of Republic of Serbia is fighting to survive in the process of transition. Based on previous experiences, in fact, the more the technology is available and engaged in production, there is a lesser need for manufacture, therefore, in the situation of full employment, the economy walks towards the destruction (Perić, 2016). Obviously, it encounters another paradox in economy, but empirically proved above.

Savings have very strong positive correlation to export (0.903), as expected. Saving within banks in Serbia are three times larger in 2016 than in 2005, more than 9 million versus less than 3 million euros, respectively. The countries of South-East Asia, for example, are well known for their population savings. However, in Serbia savings are not at the same level, yet having impact on export, while increasing.

Productivity of work has very strong positive correlation (0.844) of course, and it is statistically significant, i.e. the more the people work the most effective (not necessarily the rule) is the quantity of production, thus creating the convenience to export. During the last years, in Serbia the medium salary enjoyed a slow increase, and productivity of work from 2005 to 2016 almost doubled, from 9.95 in 2005 to 17.77 index points in 2016 (author's calculation). According to peculiarities of employment and its decreasing trend, as noted above, thus only in the theory higher productivity of work could explain the increase in export, which is not the focus here.

Exchange rate has very strong positive correlation with exports (0.909) as well, and it is statistically significant, and without any doubt, has an impact on exports. The higher the exchange rate the higher the export, which does not mean it is good for overall economy. The explanation stands from financial point of view: appreciation or devaluation of currency is one of the key factors in the economy. In the case of appreciation of the currency (dinar) there is a smaller gap between dinar and euro, the fact good for the state economy, while for the exporters it is not the case. In the case of depreciation of dinar, instead, the gap between two currencies is larger, but better for the single exporter. Importers from abroad are willing to acquire the products from the 
Perić M., Filipović S.: Impact of export determinants on the export sector in Republic...

exporters when cheaper. It does not mean that exporter gains more while the currency is depreciated, but the importer will probably be unwilling to purchase expensive goods and services. So than, the logic of "the higher the exchange rate the higher the export" in this research is proved. Exchange rate in Serbia suffered the constant depreciation, starting from 2005 with 82.99 dinars per euro to 123.47 dinars per euro in 2016. Useful example for better understanding of this point could be the Japanese car production. Japan opened the market during the $50 \mathrm{~s}$ and $60 \mathrm{~s}$, in selling cars, for example, which were very easy to buy because of their acceptable cost and low quality, while already during the $80 \mathrm{~s}$, the quality of the cars has improved, Japanese national management changed the exchange rate and today those cars cost more because they offer the quality, too.

Consumption prices have strong inverted correlation with exports $(-0.803)$, and it is statistically significant. There is no dilemma in stating that the lower the prices the higher the export, while industrial production has very weak positive correlation to export $(0.169)$ and it is not statistically significant. It shows that industrial production weakly correlates with export, the fact that may appear questionable. In this case, it would be wrong to conclude that there is no correlation between industrial production and export, since there could be the other shape of correlation or even some no quantitative connection, it could be indirect or qualitative. Unfortunately, on the basis of very low correlation and pure quantitative analysis, one could not be able to conclude if there is some other kind of connection between the two parameters.

Figure 1. FDI in Republic of Serbia (mln euro) in the period 2007-2016

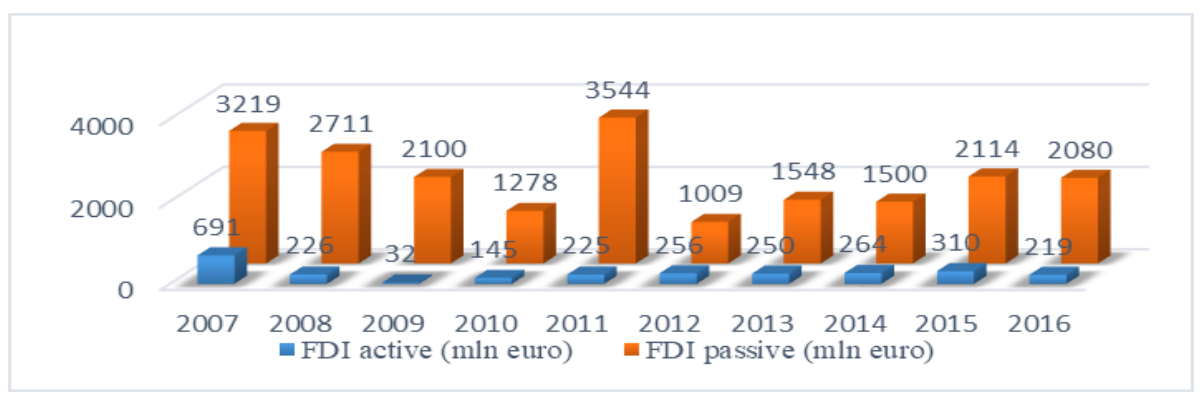

Source: Author's calculations

FDI passive has weak/genuine negative correlation with export (-0.289) which is not statistically significant, so FDI passive quantitatively is not directly correlated with export. According to this outcome, foreign investors assure insignificant contribution to the export of Republic of Serbia. FDI active has even lower correlation to export, without statistical significance as well, with 
Perić M., Filipović S.: Impact of export determinants on the export sector in Republic...

very weak negative correlation (-0.085). As reminder and clearer picture of FDI, FDI passive in 2011 had its pick with 3.5 million euros, while Republic of Serbia invested abroad only 225 hundred euros in the same year (see Figure 1).

In the view of these findings, variables such as import, GDP per capita, savings, productivity of work, and exchange rate have a very strong correlation with exports, while GDP is strongly and positively correlated to export, but population, employment, and consumption prices have a strong negative correlation to export. In relation to a very weak and not statistically significant correlation with exports, the current issue are investments, FDI, and industrial production. Although, the correlation matrix is not the faithfull represention of the "real" situation between variables, i.e. the impact of one variable to another, but only the certain degree of connection, the SLR analysis will present the impact of independent variables (export determinants) to dependent variable, in such a case the export.

Table 3. Simple Regression Models - Parameters of interest

\begin{tabular}{|c|c|c|c|c|c|}
\hline & \multicolumn{2}{|c|}{ Model Summary } & \multirow{2}{*}{\begin{tabular}{|c|} 
ANOVA \\
Regression \\
p.value \\
\end{tabular}} & \multirow{2}{*}{$\begin{array}{c}\text { Coefficients } \\
\text { Equation SRM }\end{array}$} & \multirow[b]{2}{*}{ Notes } \\
\hline $\begin{array}{l}\text { Independent } \\
\text { Variables (X) }\end{array}$ & R Square & $\begin{array}{l}\text { Adjusted } \\
\text { R Square }\end{array}$ & & & \\
\hline Import & 0.792 & 0.771 & 0.000 & $Y=-5965,59+1.064 X$ & \\
\hline GDP & 0.637 & 0.601 & 0.002 & $Y=-11003,19+0.713 X$ & \\
\hline GDP per capita & 0.714 & 0.685 & 0.001 & $Y=-10386.63+5.021 X$ & \\
\hline Population & 0.961 & 0.957 & 0.000 & $Y=218106.48-0.029 \mathrm{X}$ & \\
\hline Employment & 0.563 & 0.52 & 0.005 & $Y=61307.26-0.257 X$ & \\
\hline Savings & 0.816 & 0.798 & 0.000 & $Y=1243.45+1,452 X$ & \\
\hline Investments & 0.018 & -0.080 & 0.678 & $Y=13541.18-0.432 X$ & insignificant \\
\hline Productivity & 0.712 & 0.683 & 0.001 & $Y=-7395.96+1161.104 X$ & \\
\hline FDI active & 0.007 & -0.117 & 0.816 & $Y=12345.42-1.626 \mathrm{X}$ & insignificant \\
\hline FDI passive & 0.083 & -0.013 & 0.418 & $Y=14296.73-1.126 \mathrm{X}$ & insignificant \\
\hline Exchange rate & 0.827 & 0.809 & 0.000 & $Y=-9963.58+206,58 X$ & \\
\hline Cons. prices \% & 0.645 & 0.610 & 0.002 & $Y=15237.48-590,52 X$ & \\
\hline Ind.Prod. $2010=100$ & 0.029 & -0.068 & 0.599 & $Y=-1055.72+11.63 X$ & insignificant \\
\hline \multicolumn{6}{|c|}{$\begin{array}{l}N . B . \\
\text { Dependent variable }(Y) \text { is Export }\end{array}$} \\
\hline
\end{tabular}

Source: Author's calculations

The SLR model is engaged in order to estimate the degree of impact of export determinants on export in Republic of Serbia in the period 2005-2016. In order to avoid many pages of tables as a result of SLR for each variable, the author collected the main parametres in the Table 3 , where $R$ and $R$ square show how much the model is reliable. For example, if $R$ square is 0.75 , it means that the model is $75 \%$ trustable. The equation represents the way dependent 
Perić M., Filipović S.: Impact of export determinants on the export sector in Republic...

variable (export) changes in relation to independent variables. For example, the equation where import is chosen for independent variable is read as follows: when import is 0 export is 5965.59 million of euros negative, while the export tends to increase by $1.064 \%$ per additional unit of import, and so on for the rest of the functions. As much as functions are concerned, error terms are excluded from equations.

Also, the graphs for some simple regression results are present, both with linear and logharitmic function, in order to confirm the results obtained. If linear and loghharitmic curves tend to move to the same direction, the results are even more predictable, represented in the Figure 2. Likely to avoid pages of graphs, the Figure 2 represents only the critical and here insignificant variables in terms of impact on export. These are investments, FDls and industrial production, between which the most curious seem to be FDI active. FDI active appears questionable when obsearving the functions curves. FDI active presents the decresing linear trend in opposition to increasing logharitmic trend, meaning that in the future FDI active may show some positive impact on export, yet with prediction of low degree of direct impact.

Figure 2. Results of simple regression models in shape of graphs
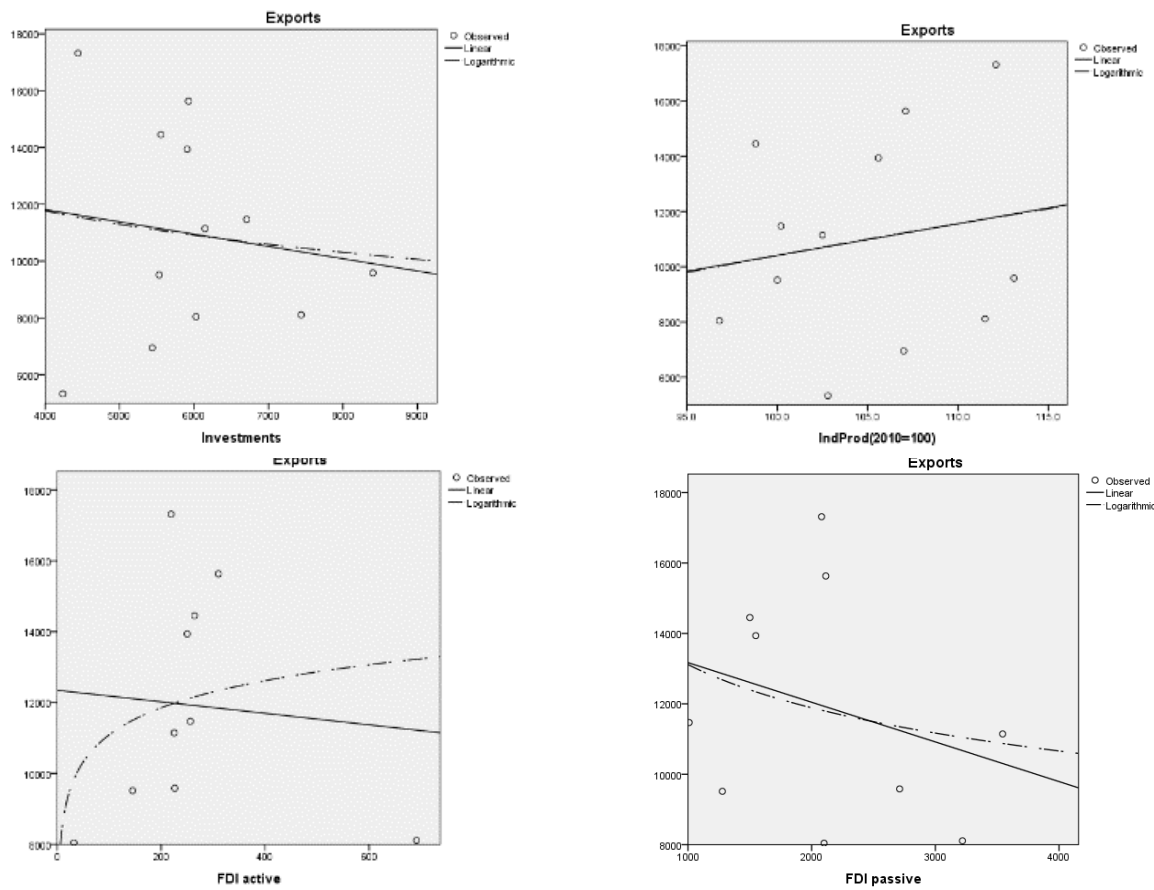

Source: Author's calculation 
Perić M., Filipović S.: Impact of export determinants on the export sector in Republic...

Taking into consideration that exports and imports make the foreign trade, the Table 4 presents the data for foreign trade in Republic of Serbia in the period 2005-2016. This is used in order to make closer the discourse to the readers and show the full macro table of foreign trade, including both exports and imports, and concretize the incurable deficit of foreign trade balance, even if in decreasing trend from 2012. The coverage of foreign trade in GDP is presented, as well.

Table 4. Foreign trade in Republic of Serbia for the period 2005-2016

\begin{tabular}{|l|c|c|c|c|}
\hline Year & $\begin{array}{c}\text { Net EXP-IMP } \\
(\mathrm{mln} \text { euro })\end{array}$ & Net EXP/IMP\% & $\begin{array}{c}\text { Export \% in } \\
\text { GDP }\end{array}$ & Import \% in GDP \\
\hline 2005 & -4283 & -0.45 & 0.25 & 0.46 \\
\hline 2006 & -5022 & -0.42 & 0.28 & 0.49 \\
\hline 2007 & -7358 & -0.48 & 0.28 & 0.53 \\
\hline 2008 & -8684 & -0.48 & 0.28 & 0.54 \\
\hline 2009 & -5056 & -0.39 & 0.26 & 0.43 \\
\hline 2010 & -4729 & -0.33 & 0.32 & 0.48 \\
\hline 2011 & -5342 & -0.32 & 0.33 & 0.49 \\
\hline 2012 & -5523 & -0.33 & 0.36 & 0.54 \\
\hline 2013 & -3845 & -0.22 & 0.41 & 0.52 \\
\hline 2014 & -3645 & -0.20 & 0.43 & 0.54 \\
\hline 2015 & -3538 & -0.17 & 0.47 & 0.56 \\
\hline 2016 & -2581 & -0.13 & 0.51 & 0.58 \\
\hline
\end{tabular}

Source: Author's calculations based on data from NBS main macroeconomic indicatiors

The author converted the data from NBS in dinar to euro using the average real exchange rate of the compatible year. Net EXP/IMP shows the coverage, i.e. how much import overcomes export. Import covered export, e.g. in 2005 by $45 \%$. In other words, in 2005 , import was almost double comparing to export, while in 2007 import covered export only by $13 \%$. Foreign trade plays an important role in national accounts: as in the table above, exports' participation in the GDP is $25 \%$ in the beginning of the period concerned. The participation of export sector in GDP shows the increasing trend until 2016. Only in the post-crisis year, in 2009, export participation in GDP decreased by $2 \%$, comparing to its participation in the previous year, which is very small decrease in comparison with the financial world crisis. At the end of 2016, export reached the participation of $51 \%$ in GDP of Republic of Serbia. This data shows how significant the exports are for Serbian economy. The problem is the constant increase of imports' participation in GDP, which arrived to cover $58 \%$ of GDP in 2016, and yet do not permit export to overcome import. 
Perić M., Filipović S.: Impact of export determinants on the export sector in Republic...

In this part of research, application of SLR models defined the degree of impact of significant variables in export. According to the results obtained by conducting the SLR, the following variables impact export in the up-bottom view: population, exchange rate, savings, imports, productivity of work, GDP per capita, consumption prices, GDP, employment.

It follows the MLR analysis, defining exports as dependent variable, and population, exchange rate, savings, imports, productivity of work, GDP per capita, consumption prices, GDP, employment as independent variables.

Model Summary

\begin{tabular}{|l|l|l|l|l|}
\hline Model & $R$ & R Square & Adjusted R Square & $\begin{array}{l}\text { Std. Error of the } \\
\text { Estimate }\end{array}$ \\
\hline 1 & $.998^{\mathrm{a}}$ & .995 & .982 & 492.512 \\
\hline
\end{tabular}

a. Predictors: (Constant), Consprices\%trend, Employment, Import, ExchangeRate, GDP, Savings, Population, Productivity

ANOVA $^{\mathrm{a}}$

\begin{tabular}{|ll|l|l|l|l|l|}
\hline Model & & Sum of Squares & df & Mean Square & F & Sig. \\
\hline 1 & Regression & 151226448.314 & 8 & 18903306.039 & 77.930 & $.002^{\mathrm{b}}$ \\
& Residual & 727703.936 & 3 & 242567.979 & & \\
& Total & 151954152.250 & 11 & & & \\
\hline
\end{tabular}

a. Dependent Variable: Exports

b. Predictors: (Constant), Consprices\%trend, Employment, Import, ExchangeRate, GDP, Savings, Population, Productivity

\section{Coefficients $^{\mathrm{a}}$}

\begin{tabular}{|c|c|c|c|c|c|c|}
\hline \multirow[b]{2}{*}{ Model } & & \multicolumn{2}{|c|}{$\begin{array}{l}\text { Unstandardized } \\
\text { Coefficients }\end{array}$} & \multirow{2}{*}{$\begin{array}{l}\text { Standardized } \\
\text { Coefficients } \\
\text { Beta } \\
\end{array}$} & \multirow[b]{2}{*}{$t$} & \multirow[b]{2}{*}{ Sig. } \\
\hline & & $B$ & Std. Error & & & \\
\hline 1 & (Constant) & 26390.149 & 268752.931 & & .098 & .928 \\
\hline & Import & .374 & .248 & .313 & 1.510 & .228 \\
\hline & GDP & -1.816 & 2.211 & -2.032 & -.821 & .472 \\
\hline & Population & -.014 & .022 & -.489 & -.655 & .559 \\
\hline & Employment & 386 & .519 & 1.129 & .744 & .511 \\
\hline & Savings & .673 & 1.214 & .419 & .555 & 618 \\
\hline & Productivity & 3469.019 & 4705.407 & 2.521 & .737 & .514 \\
\hline & ExchangeRate & 31.519 & 128.856 & .139 & .245 & .823 \\
\hline & Consprices\%trend & -68.415 & 60.567 & -.093 & -1.130 & .341 \\
\hline
\end{tabular}

a. Dependent Variable: Exports 
Perić M., Filipović S.: Impact of export determinants on the export sector in Republic...

\section{Excluded Variables ${ }^{a}$}

\begin{tabular}{|c|c|c|c|c|c|c|}
\hline & & & & & & $\begin{array}{l}\text { Collinearity } \\
\text { Statistics }\end{array}$ \\
\hline Model & & Beta In & $\mathrm{t}$ & Sig. & Partial Correlation & Tolerance \\
\hline 1 & GDPpercapita & $29.090^{6}$ & 13.259 & .006 & .994 & $5.596 \mathrm{E}-6$ \\
\hline
\end{tabular}

a. Dependent Variable: Exports

b. Predictors in the Model: (Constant), Consprices\%trend, Employment, Import, ExchangeRate, GDP, Savings, Population, Productivity

When conducting the SLR models, FDI, investments, and industrial production resulted not to be statistically significant, while running the MLR analysis shows that none of the independent variables are statistically

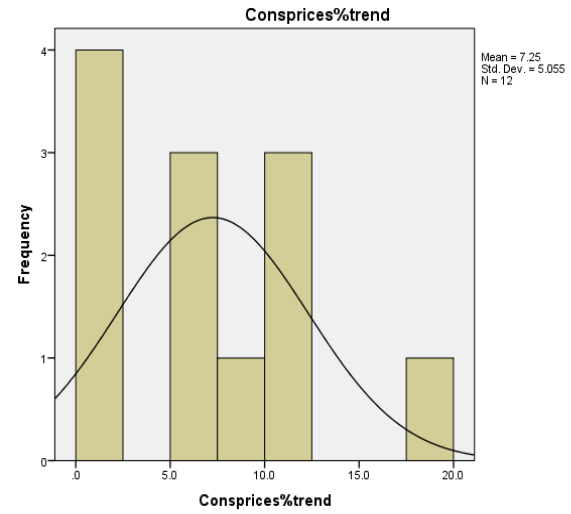
significant. It is possible that the real process that generated the data used here is not linear nor logistic. In fact, verifying the distribution of frequencies of parameters through "smart charts", the frequencies are much dispersed (as an example see the graph on the left).

The explanation of no statistical significance in MLR analysis relies on two facts: first, the distribution of frequencies of each variable showed high irregular dispersion of data. Second, the number of data points is small, which does not probably allows the software to produce some statistical significance when collinearity of variables is included, the fact that could be even possible if the distribution of frequencies of variables were linear and regular. In other words, it is probable that the multiple regression would not produce the expected result for only 12 data points, if and only if the frequencies of variables are distributed in blocks (see example on the graph above on the left).

But, since the main aim of this research is to discover the impact of each variable on export, and not to discover the impact of sum of variables on export, the impossibility of obtaining statistical significance from MLR analysis do not bother the research.

This paper demonstrated that the frequencies of variables possess a dispersed distribution, which by consequence prevent the MLR analysis to produce the statistical significance for data point in examination. Thus, the research was not conducted in order to demonstrate the collinearity between 
Perić M., Filipović S.: Impact of export determinants on the export sector in Republic...

independent variables and their overall impact on the dependent variable, in this case export, since the interest of this research is to be useful to researches and policy makers to focus on improving the performance of some chosen variable and deal with promoting each export sector. Policy recommendations are "learned" by lessons. For example, Brazil promoted its exports through import substitution model. Instead, the lesson from Asian countries is the stable macroeconomic environment (stable real exchange rate and inflation, reallocation of activities, constant export promotion, import controls, upgrading human capital), from Latin America is the unstable macroeconomic environment (high inflation rates and highly appreciated exchange rate), comparing to lessons from developed countries (investments in infrastructure, regulatory environments, FDI for improving and extending efficiency) etc.

Old or wrong industrial infrastructure limits the possibility of increasing productivity. For this reason, there is a need for constant modernization of industrial infrastructure, which require responsibility and improvement in work organization. If process of transition gave positive results in most of the countries, why it should not for Serbia? For some, privatization process, application of monetary and fiscal policy concentrated on the macroeconomic stability brings down the production and lateness in transactions, and for some others, the fall in production is the consequence of initial conditions and external shocks because of why there is a need for (new) macroeconomic policy. Since Serbia applied reforms of privatization and EU integration, there is no overcoming of exports in regards to imports, and exchange rate is in continuing devaluation until the beginning of 2017.

Serbia should attract national investments and stimulate investments in innovations and higher value added sectors of industry. Surely foreign investors believe in Serbian reliability and dynamism, but their profits are transfered to their countries. Also, profits made in Serbia should stay in Serbia. Beside economical issues, political instability, slow modernization of industry and low level of governmental competence and competiveness, messed legislation should find the new approach.

\section{Conclusions}

The aim of this research was to estimate the degree of correlation and impact of export determinants to exports. This research proved that FDI, investments and industrial production have no quantitative correlation niether impact on exports, while import, GDP, GDP per capita, population, employment, savings, productivity of work, exchange rate, consumption prices, do. Particular recommendation to whom it may concern is the attention to 
Perić M., Filipović S.: Impact of export determinants on the export sector in Republic...

exchange rate, as the most sensible determinant of export from financial point of view, since a certain devaluation of exchange rate could benefit the export, but not the overall economy, and vice versa. Both import and export strongly depend on exchange rate because of its appreciation and depreciation.

In the global competitiveness countries' objective is to capture a larger share of the global market, which happens through exports basically. There is a set of suggestions made to this end, which falls into two categories: (1) improving policy-makers decisons in supporting export sector, and (2) data collection by delegated institutions in order to provide researches with the information to engage in further investigation.

Policy-makers are invited to dedicate added attention for export promotion policies in the line with strategies for improving export sector performance and profitability. When considering export promotion, policy-makers should think of not spending but investing, and they should require a (positive) feedback and control the rate of return of export promotion. In the microeconomic view, each company requires a successful business, which requires, inter alia, suitable laws and procedures that guarantee the measure of success in business, and control of corrupted institutions or members of such institutions.

Finally, some issues for further research could be pointed out. In the first place the institutions of competence should collect data and add to statistics the human capital, number of graduated people that are employed, and index of productivity of work in sense of quality. In the second place, relationship between these data can be evaluated by researcher using different methodologies which will contribute, basically, to the science and national economy. In other words, analysis based on scientific research should be used in creation of economic policy which is known as evidence based policy approach. Also, the proposal is to conduct a reseach in tariffs and quotas or investigate foreign trade of Serbia under "existing protections of national products".

\section{References}

CEFTA (2006). Sporazum o slobodnoj trgovini na Balkanu. Ministarstvo za evropske integracije. Retrieved from http://seio.gov.rs/scr/dokumenta/sporazumi-saeu/sporazum-o-slobodnoj-trgovini-na-balkanu-cefta

Chou, C., Chu, C., \& Liang, G. (2008). A modified regression model for forecasting the volumes of Taiwan's import containers. Mathematical and Computer Modelling, 47(9-10), 797-807. doi:10.1016/j.mcm.2007.05.005

Duenas-Caparas, M. T. S. (2007). Firm-Level Determinants of Export Performance: Evidence from the Philippines. Philippine Journal of Development, 34(62), 87107. 
Perić M., Filipović S.: Impact of export determinants on the export sector in Republic...

Filipovic, S., \& Miljkovic, M. (2014). Transition economies during global economic crisis: A difference in differences approach. Industrija, 42(3), 23-39. doi:10.5937/industrija42-6944

Knobel, A. (2016). Export-Import: Era of Stagnation. Russian Economic Developments, 1, January, $42-45$.

Krušković, B.D. (2017). Exchange Rate and Interest Rate in the Monetary Policy Reaction Function. Journal of Central Banking Theory and Practice, 6(1), doi:10.1515/jcbtp-2017-0004

Kunwang, L. \& Bingzhan, S. (2013). A new model of growth and development. Determinants of Chinese exports in information and communication technology (ICT) products: A firm-level analysis. ANU Press.

Lall, S., Weiss, J. \& Zhang, J. (2005). The 'Sophistication' of Exports: A new Measure of Product Characteristics (Discussion Paper No. 23, January). ADB Institute, Tokyo.

Leamer, E.E. (1980). The Leontief Paradox, Reconsidered. Journal of Political Economy, 88(3), 495-503. doi:10.1086/260882

Makojevic, N., Kostic, M., \& Puric, J. (2016). Can the state influence FDI regional distribution: The case of Czech Republic, Hungary, Poland and Serbia. Industrija, 44(2), 43-54. doi:10.5937/industrija44-9590

MAT, FREN. (2010). Postkrizni model provrednog rasta i razvoja Srbije 2011-2020, USAID, Beograd, 2010.

Nikolić, G. (2005). Uticaj spoljne trgovine na ekonomski rast. Ekonomski anali, 50(165), 145-164. doi:10.2298/eka0565145n

Nikolić, G. \& Bodroža, D. (2012). Positioning and re-positioning of national brand of Serbia in order to increase exports, foreign direct investments and tourism development. In Managing Structural Changes - Trends and Requirements (vol. 1) Institute of Economic Science (pp. 488-505).

Pakhomov, A. (2015). Russian export in 2014: trends and development problems. Russian Economic Developments, February, 2, 38 - 41.

Pažun, B., Longović, Z. \& Milićević, A. L. (2016). Equilibrium real exchange rate assessment of the serbian dinar: the MB approach. Romanian Journal for Economic Forecasting, 19(1), 76-87.

Perić, M. (2016). Brazilian Economy in the XXI century. Edizioni Accademiche Italiane, Italy. ISBN: 978-3-330-77750-7

Petrović, P. (2010). Uticaj ljudskih resursa na privredni rast Srbije. Ljudski kapital i spoljnotrgovinska razmena. Ekonomski horizonti, 12(1), 103-109. DOI. 330.341:005.336.4.

Radojević, T., Sarac, M., Radovanović, D, \& Stanišić, N. (2015, September). The advantages of Serbia for Foreign Direct Investments. Paper presented at the 19th International Accademic Conference, Florence. DOI: 10.20472/IAC.2015.019.115

Vasić, J., Kecman, N., \& Mladenović, I. (2016). Research and Development Investment as Determinant of International Competitiveness and Economic Growth in Eu28 and Serbia. Economic Themes, 54(2), doi:10.1515/ethemes2016-0010

Vukovic, A., Ubiparip, D., Radovanovic, M., \& Jacimovic, S. (2015). Fresh Tomato: Promising export product for Serbia. Industrija, 43(3), 171-189. doi:10.5937/industrija43-9166 
Perić M., Filipović S.: Impact of export determinants on the export sector in Republic...

Zhang, Q. (2012). The role of FDI, exports and spillover effects. In Dilemmas of China's growth in the Twenty-First century. ANU Press.

Zubritskiy, A. (2014). Ukrainian Export Diversification: Macro Level Analysis. Financial Law Research Institute, MPRA Paper No. 70585, December 20. Retrieved from https://mpra.ub.uni-meunchen.de/70585/ 